\title{
Plasmapheresis in the initial treatment of insulin-dependent diabetes mellitus in children
}

\author{
JOHNNY LUDVIGSSON， LISE HEDING，GUDRUN LIEDÉN， BIRGITTE MARNER, \\ AKE LERNMARK
}

\begin{abstract}
Several factors indicate that autoimmune mechanisms may play a part in the aetiology of insulin-dependent diabetes mellitus. At the onset of the disease in 10 children (aged 11-16 years) plasmapheresis was performed four times over one to two weeks. Seventeen age-matched children with the same clinical features served as controls. The C-peptide concentrations at onset were the same in the two groups, but after one month the children treated with plasmapheresis had significantly higher values. This difference became even more pronounced after three, nine, and 18 months, both during fasting and at the maximum response to a standardised meal. The study group also had a significantly more stable metabolism, longer partial remission, and no higher insulin requirement. Of the 10 treated children islet-cell cytoplasmic antibodies were present in seven before plasmapheresis and in nine during treatment. The antibodies remained detectable in five and six out of nine patients at one and six months respectively after plasmapheresis. Although the mechanisms are obscure, plasmapheresis performed at the onset of insulindependent diabetes mellitus may help to preserve betacell function.
\end{abstract}

\section{Introduction}

Several factors indicate that autoimmune mechanisms may be concerned in the aetiology of insulin-dependent diabetes mellitus. ${ }^{2}{ }^{2}$ Because of the poor prognosis of the disease in children $^{3}{ }^{4}$ we considered it justified to use repeated plasmapheresis in the treatment of the disease on the basis that an autoimmune destructive process is in progress at the onset and that noxious agents can be removed or neutralised by the plasma exchange.

\section{Patients and methods}

All newly diagnosed diabetic children within the Linköping area are referred to our clinic. The study group included 10 newly diagnosed insulin-dependent diabetics in whom the disease had started between 1979 and 1980 and who had suitable blood vessels. All of the parents gave their informed consent. The study was approved by the ethics committee at Linköping University Hospital.

Seventeen age-matched patients in whom the disease had started between 1976 and 1980 served as controls. There were no distinct differences between the groups at the time of diagnosis (table).

University Hospital, Linköping, Sweden

JOHNNY LUDVIGSSON, MD, associate professor of paediatrics GUDRUN LIEDEN, MD, head of the blood centre

Novo Research Institute, Bagsvaerd, Denmark

LISE HEDING, MSC, PHD, head of the medical department

Hagedorn Research Laboratory, Gentofte, Denmark

BIRGITTE MARNER, MD, research fellow

ÅKE LERNMARK, MD, head of Hagedorn Research Laboratory
Identical information and psychological support was given to all patients and their families; they could telephone a specially trained nurse for extra consultations and a dietitian for help and advice regarding their food.

Plasmapheresis-This was performed by intermittent flow centrifugation using a Haemonetics 30 cell separator (Braintree, Mass, USA). Acid citrate dextrose solution (National Institutes of Health solution A) or saline with sodium citrate was used as anticoagulant. The plasma removed was substituted mainly by blood donor plasma, partly freshfrozen, and saline. As substitution and removal of plasma occur simultaneously the amount of plasma exchanged in the patient is less than the volume removed by the cell separator; the actual proportion of the plasma exchanged in each patient was calculated according to the formula $1-\mathrm{x}=1-\mathrm{e}_{-}$) where $\mathrm{x}$ is the proportion of the patient's plasma remaining in the circulation after apheresis, $v$ is the volume removed, and $p$ the plasma volume of the patient.

Serum C-peptide concentrations-These were determined according to Heding. ${ }^{5}$ Islet-cell cytoplasmic antibodies were detected by an indirect immunofluorescence test using cryostat sections of pancreatic tissue from patients with blood type $0 .{ }^{6} \mathrm{HLA}-\mathrm{DR}$ antigens were typed according to Dahlbergh et al. ${ }^{7}$ Urinary glucose concentrations were determined using the Clinitest (Ames) two-drops method.

Degree of metabolic control-This was evaluated on the basis of the daily urine tests. The number of urine tests without glycosuria expressed as a percentage of all tests performed was taken as an index of control. ${ }^{8}$

Early partial remission-This was defined according to the International Study Group of Diabetes in Children and Adolescents ${ }^{9}$ as a period of at least one month soon after the onset with or without minimal glycosuria and with an insulin requirement of less than $0.5 \mathrm{IU} / \mathrm{kg}$ body weight. We classified "no or minimal glycosuria" as $100 \%, 90-99 \%$, or $80-89 \%$ of the daily urine tests with negative results for glucose.

\section{CLINICAL MANAGEMENT}

All 27 patients were admitted to hospital at the onset of the disease and treated actively with multiple injections of monocomponent insulin (Novo) to stabilise metabolism as rapidly as possible. After this initial period of 2-3 days the patients were treated with a combination of short-acting and intermediate-acting monocomponent insulin twice daily, diet, and regular physical exercise.

In the study group plasmapheresis started immediately after the initial stabilisation. Four aphereses were performed over 4-11 days (mean $7 \cdot 7$ days) in nine patients. In one patient only one complete

Clinical symptoms and laboratory variables at the onset of diabetes mellitus in the study group and the controls

\begin{tabular}{|c|c|c|}
\hline & Study group $(n=10)$ & Controls $(n=17)$ \\
\hline Age (years) & $11-16($ mean 13.0$)$ & $10-16($ mean $12 \cdot 3)$ \\
\hline$\stackrel{\operatorname{Sex}}{\underset{F}{M}}$ & - & (2) - \\
\hline $\begin{array}{l}\text { Symptoms } \\
\text { Very slight } \\
\text { Moderate } \\
\text { Severe }\end{array}$ & $\begin{array}{l}2 \\
6 \\
2\end{array}$ & $\begin{array}{c}6 \\
11 \\
0\end{array}$ \\
\hline $\begin{array}{l}\text { Blood glucose concentration } \\
\text { (mmol/1) } \\
\text { Ketonuria }\end{array}$ & $15 \cdot 1-60 \cdot 0\left({ }_{8}\right.$ mean $\left.28 \cdot 1\right)$ & $13 \cdot 8-49 \cdot 9 \underset{16}{(\text { mean } 22 \cdot 0)}$ \\
\hline $\begin{array}{l}\text { C-peptide concentration } \\
\text { (pmol } / \mathrm{ml} \text { ) }\end{array}$ & $0.05-0.43($ mean 0.24$)$ & $0.05-0.55$ (mean 0.22$)$ \\
\hline $\begin{array}{l}\text { HLA antigens } \\
\text { DR3 } \\
\text { DR3/4 } \\
\text { DR4 } \\
\text { Other } \\
\text { Not typed }\end{array}$ & $\begin{array}{l}1 \\
8 \\
1\end{array}$ & $\begin{array}{l}2 \\
4 \\
7 \\
1 \\
3\end{array}$ \\
\hline
\end{tabular}


apheresis was performed owing to vascular problems. A mean volume of $1435 \mathrm{ml}$ of plasma was removed at each apheresis, which constituted $39-69 \%$ (mean $55 \pm 7 \cdot 1 \%$ ) of the patient's plasma volume according to the above formula.

Samples for detecting islet-cell antibodies ${ }^{6}$ were collected at the onset before the first insulin injection after completion of plasmapheresis and at one and six months later. The results were not available when the decision to perform plasmapheresis was made.

Serum samples for C-peptide analysis were collected at the onset of diabetes before the first insulin injection and then at three days, one, three, six, nine, 18, and 30 months after onset in all patients. At three, nine, 18 , and 30 months the patients were given a standardised breakfast ${ }^{10}$ and maximum serum $\mathrm{C}$-peptide response was determined.

After discharge the effect of treatment was assessed by glucose estimations in single-voided urine specimens $2-4$ times every day. The results were recorded in a diary and shown to the doctor at the followup visits every $2-3$ months.

Wilcoxon's test for two samples was used for statistical analysis.

\section{Results}

Apart from the discomfort caused by the use of large needles plasmapheresis had no side effects, with the exception of urticaria which developed in one patient when transfused with plasma; this was then replaced by isotonic saline and albumin. Blood glucose concentrations could be kept within normal or near normal range during plasmapheresis.

The indirect immunofluorescence test for islet-cell antibodies showed that seven of the 10 children were antibody-positive before plasmapheresis. The prevalence increased to nine out of 10 during treatment and to six and five out of nine at one and six months respectively after treatment.

The children who were treated with plasmapheresis had significantly higher serum C-peptide concentrations. These were the same in the two groups at onset, before the first insulin injection, and at day 3 before the start of plasmapheresis (fig 1). During plasmapheresis there were no significant changes, but one month later fasting serum $C$ peptide values were significantly higher in the study group (fig 1). The difference was still more pronounced at three months particularly in relation to the maximum response to the standardised breakfast load. At nine months there was a significant difference both in fasting C-peptide and maximum response values among the study patients; so far these values have been measured in only seven children at 18 months after onset and in three at 30 months. The C-peptide values were much higher in the study patients than the control patients when fasting and at the maximum response $(p<0 \cdot 05-0 \cdot 01)$.

Residual beta-cell function was better maintained in the study group and was accompanied by a significantly more stable metabolism during the follow-up period. Thus seven of 10 patients in the study group had a partial remission for more than six months compared with four of 17 controls $(p<0 \cdot 01)$ (fig 2$)$. All the study group had a very stable period
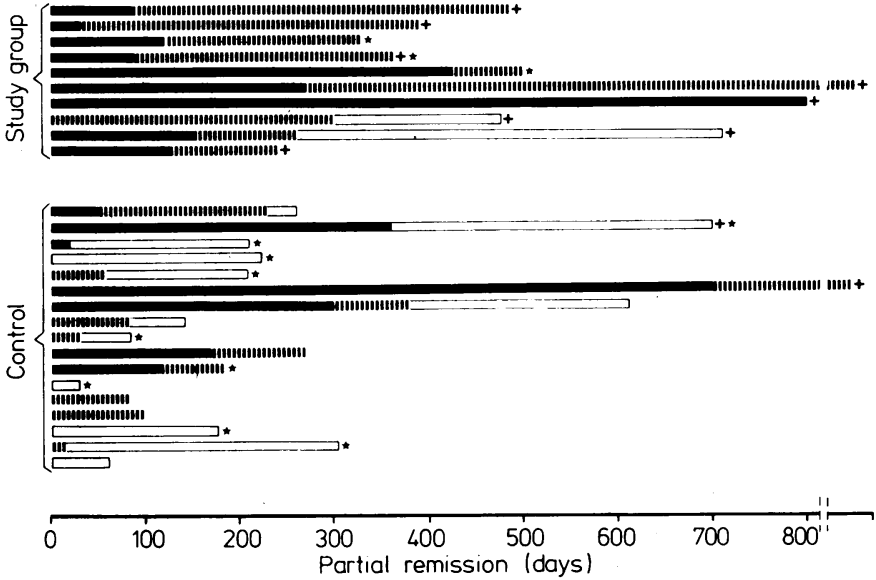

FIG 2-Early partial remission periods in 10 patients treated with plasmapheresis at onset compared with 17 controls. No or minimal glycosuria in 2-4 daily single-voided urine specimens was classified as: $=100 \%$, $\mathbf{0}=90-99 \%$, and $\square=80-89 \%$ of urine tests without glycosuria. +indicates continuation of the stable period; $t=$ indicates an insulin requirement of more than $0.5 \mathrm{IU} / \mathrm{kg}$ body weight.

for more than six months (fig 2) although three cases could not be classified as partial remissions as they required more insulin than $0.5 \mathrm{IU} / \mathrm{kg}$ body weight over 24 hours. Two of these three patients had severe ketoacidic symptoms on admission to hospital, while none of the controls had such severe symptoms at onset. Mean insulin requirements during the remission period in the study group was $0.45 \mathrm{IU} / \mathrm{kg}$ body weight compared with $0.56 \mathrm{IU} / \mathrm{kg}$ body weight in the controls (NS).

\section{Discussion}

Plasmapheresis has been used therapeutically in several diseases $^{11}$ on the basis that some disease processes are associated with the presence of autoantibodies. Whether the autoantibodies are concerned in either the aetiology or the pathogenesis of the disease removal by apheresis should cause clinical improvement. IgG antibodies can be effectively removed from experimental animals by exchange transfusion, but a rapid rebound occurs within a week after exchange ${ }^{12}$; this can be partially suppressed with cyclophosphamide. ${ }^{13}$ There is good evidence that plasma exchange will decrease circulating immune complexes, but it is not clear that such a decrease can be directly related to the clinical course of a disease. ${ }^{14}$ In patients with immune complex rheumatoid disease, for example, remission is often maintained after plasmapheresis despite the return of circulating immune complexes to pre-exchange values. ${ }^{15}$

Plasmapheresis has had beneficial effects in a patient with insulin-resistant diabetes associated with autoantibodies to the insulin receptor. ${ }^{16}$ In three of our patients no islet-cell antibodies were present before plasmapheresis but in two they were found after treatment. The possibility that the decreased prevalence at one and six months was due to plasmapheresis is impossible to judge since it is well known that the prevalence of islet-cell antibodies decreases with increased duration of the disease. In our study we found the beneficial effect led to a more stable metabolism and improved beta-cell function in classical juvenile insulin-dependent diabetics. The difference in insulin dose given to the study patients and to the controls may seem small, but we
IG 1-Serum C-peptide concentrations showing fasting values and maximum response to a standardised breakfast in patients treated with plasmapheresis compared with controls. 
considered the degree of metabolic control to be a more reliable index of improvement; the controls would probably have required higher doses of insulin to achieve as good a metabolic balance as the study patients. The beneficial effect on beta-cell function seems unquestionable, as do the longer partial remissions in the study group.

The differences between the study patients and the controls could be explained by defects of methodology or study design. But a double-blind randomised study would only be possible if the patients could be subjected to some type of "placebo" exchange. For ethical and psychological reasons this was unacceptable. Furthermore, we considered it to be psychologically impossible to recommend an invasive rather stressful treatment to some and not to other newly diagnosed children. Thus the patients treated with plasmapheresis were not chosen randomly but consecutively during 1979 and 1980; only those who lacked suitable blood vessels were excluded. We compared these children with all patients of the same age at onset and with the same clinical features at onset, during treatment, and at follow-up.

In patients with HLA-DR3 antigens the onset may be milder and remissions may occur more often than in patients with HLA-DR4 and DR3/4 antigens (unpublished data). This cannot explain the difference, however, as the study group included only one patient with HLA-DR3 and two patients who had no or very slight symptoms at onset compared with two with DR3 and six out of 17 with very slight symptoms at onset among the controls. Moreover, two of the study patients but none of the controls had severe ketoacidotic symptoms at onset.

Urine tests were used as the only index of the degree of metabolic control, as we had no reliable method for routinely determining glycosylated haemoglobin concentrations until 1980. The controls and the study patients carried out the same number of daily urine tests. For well-informed young diabetics, with normal or low renal thresholds for glucose, determination in single-voided urine fractions over most of the 24 hours provided adequate information on whether the blood glucose concentrations were too high or not. ${ }^{8}$ Furthermore, this index is well correlated with glycosylated haemoglobin concentrations. ${ }^{17} 18$ Similarly, the definition of partial remission, which may be slightly imprecise for adult-onset diabetes, has proved to be useful and relevant in diabetic children. ${ }^{\circ}$ Despite any defects in the definition this cannot explain the differences between the study group and the controls.

It is possible that the improved metabolic control and prolonged partial remission could stem from a "placebo" effect of the plasmapheresis. We do not, however, give patients undergoing plasmapheresis any special attention but regard them as part of the routine work of our diabetic clinic. Some psychological effect on the patients, however, is unavoidable, but this could not account for the improved metabolic control or the significantly improved beta-cell function at 18 months or longer after onset. ${ }^{18}$

Thus plasmapheresis appears to have some positive biochemical effect which helps to preserve beta-cell function. The removal of the patient's plasma may reduce the amount of autoantibodies, ${ }^{12}$ complement, or other inflammatory mediators. ${ }^{20}$ The replacement with plasma from healthy donors could also affect the immunological balance, ${ }^{21}$ for example, by blocking autoantibody-receptors (antigens) on the beta-cell surface by unspecific antibodies, ${ }^{22}$ by replacing low-affinity antibodies with high-affinity ones, ${ }^{23}$ or by adding substances which diabetics need to counteract progressive beta-cell destruction.

The removal of plasma may reduce the antibody concentrations for a short time but then lead to an increase because of a rebound effect. ${ }^{11} 12$ Such an effect might have possibly occurred in our patients since two of them had islet-cell antibodies during plasmapheresis. For this reason plasmapheresis is usually combined with immunosuppression in the treatment of certain other immunological diseases. ${ }^{14}{ }^{24}{ }^{25}$ We did not use immunosuppression for two reasons. Firstly, we wanted to see the possible effects and side effects of plasmapheresis alone and, secondly, we were not ready to recommend two radically new treatments until we knew more about the effect of each one separately. Thus, in another parallel study we have used prednisolone at the onset, ${ }^{26}$ the results of which will influence the design of future studies.

Although no side effects were found, except urticaria in one patient, plasmapheresis may cause other side effects such as hepatitis, coagulation defects, thrombocytopenia, hypogammaglobulinaemia, hypocomplementaemia, or electrolyte imbalance. Since it is also expensive we do not recommend plasmapheresis as routine treatment at the onset of insulin-dependent diabetes mellitus in children. The short-term effects are sufficiently promising, however, to justify further studies.

\section{References}

1 Nerup J, Lernmark $\AA$. Autoimmunity in insulin-dependent diabetes mellitus. $A m \mathcal{F}$ Med 1981;70:135-41.

${ }^{2}$ Handwerger BS, Fernandes G, Brown DM. Immune and autoimmune aspects of diabetes mellitus. Hum Pathol 1980;11:338-52.

${ }^{3}$ Korpela P, Peltonen T, Kallio V, Mäkelä A-L. Prognosis for juvenile diabetics. Acta Endocrinol 1979;suppl 227:43-4.

4 Larsson Y, Sterky G, Christiansson G. Long-term prognosis in juvenile diabetes mellitus. Acta Paediatr Scand 1962;51 suppl: 130.

${ }^{5}$ Heding LG. Radioimmunological determination of human C-peptide in serum. Diabetologia 1975;11:541-8.

${ }^{6}$ Botazzo GF, Florin-Christensen A, Doniach D. Islet cell antibodies in diabetes mellitus with autoimmune polyendocrine deficiencies. Lancet 1974 ;ii :1279-83.

7 Dahlberg PA, Holmlund G, Karlsson FA, Säfwenberg J. HLA-A, -B, -C, and DR-antigens in patients with Grave's disease, and their correlations with signs and clinical course. Acta Endocrinol 1981;97:42-7.

${ }^{8}$ Ludvigsson J. Metabolic control in juvenile diabetes mellitus. Linköping University Medical Dissertations No 42. Linköping, Sweden:1976.

- Akerblom H. The definition of remission. In: Paediatric and adolescent endocrinology. Basel: Karger (in press).

${ }^{10}$ Ludvigsson J, Heding LG. Beta-cell function in children with diabetes. Diabetes $1979 ; 27$ suppl $1: 230-4$.

11 Grindon AJ. Partial plasma exchange. A critical review. In: Berkman EM, Umlas J, eds. Therapeutic hemapheresis. Washington DC: American Association of Blood Banks, 1980

12 Bystryn JC, Graf MW, Uhr JW. Regulation of antibody formation by serum antibody. $\mathcal{F}$ Exp Med 1970;132:1279-87.

13 Auerbach R, Bystryn JC. Plasmapheresis and immunosuppressive therapy. Arch Dermatol 1979;115:728-30.

14 Berkman EM, Umlas J, eds. Therapeutic hemapheresis. A technical workshop. Washington DC: American Association of Blood Banks, 1980.

15 Simon TL, Goldman R, Tung KSK. Relationship between circulating immune complexes and plasmapheresis. Transfusion 1979;19:667.

${ }^{16}$ Muggeo M, Flier JS, Abrams RA, Harrison LC, Deisserroth AB, Kahn CR. Treatment by plasma exchange of a patient with autoantibodies to the insulin receptor. $N$ Engl $\mathcal{F}$ Med $1979 ; 300: 477-80$.

17 Topper D, Doron M, Karp M, Laron Z. Glycosylated hemoglobin as an index of control in insulin-dependent diabetic children and adolescents. Bulletin of International Study Group on Diabetes in Children and Adolescents $1979 ; 3: 18-20$.

18 Lanoe R, Thibult N, Eschwege E, Soria J, Soria C, Tchrobroutsky G. Glycosylated haemoglobin concentrations and Clinitest results in insulin-dependent diabetes. Lancet $1977 ;$ ii : 1156.

19 Madsbad S, Binder C, Faber OK, Krarup T, Regeur L. The effect of strict metabolic control on residual $\beta$-cell function, a controlled study. Diabetologia 1980;19:296.

20 Clough JF, Calabrese LH. Theoretical aspects of immune complex removal by plasmapheresis. Plasma Therapy $1981 ; 2: 73$.

\&1 Nusbacher J, Marder VJ, Anderson FW. Long-term follow-up of 15 patients with idiopathic thrombocytopenic purpura (ITP) treated by plasma exchange. Transfusion $1979 ; 19: 666$

22 Imbach $\mathrm{P}$, Barandun $\mathrm{S}$, d'Apuzzo $\mathrm{V}$, et al. High-dose intravenous gammaglobulin for idiopathic thrombocytopenic purpura in childhood. Lancet $1981 ; \mathrm{i}: 1228-30$

23 Anonymous. Plasmapheresis and immunosuppression. Lancet 1976;i 113-4.

24 Dau PC, Lindstrom JM, Cassel CK, Denys EH, Shev EE, Spitler LE. Plasmapheresis and immunosuppressive drug therapy in myasthenia gravis. N Engl f Med 1977;297:1134-40.

${ }^{25}$ Lookwood CM, Rees AJ, Pearson TA, Evans DJ. Immunosuppression and plasma-exchange in the treatment of Goodpasture's syndrome. Lancet $1976 ; \mathrm{i}: 711-5$.

2 Ludvigsson J, Heding LG, Lernmark $\AA$, Liedén G. An attempt to break the autoimmune process at the onset of IDDM by the use of plasmapheresis or high doses of prednisolone. Bulletin of the International Study Group of Diabetes in Children and Adolescents. 1982;6:11-2.

(Accepted 4 October 1982) 